\title{
TNF $\alpha$ mediates susceptibility to heat-induced apoptosis by protein phosphatase-mediated inhibition of the HSF1/hsp70 stress response
}

\author{
G Schett $^{\star, 1}, \mathrm{C}-\mathrm{W}$ Steiner ${ }^{1}, Q \mathrm{Xu}^{2}$, JS Smolen ${ }^{1}$ and G Steiner ${ }^{1,3}$ \\ 1 Division of Rheumatology, Department of Internal Medicine III, University of \\ Vienna, Austria \\ 2 Department of Cardiological Sciences, St. George's Hospital Medical School, \\ London, UK \\ 3 Center of Molecular Medicine of the Austrian Academy of Sciences, Vienna, \\ Austria \\ * Corresponding author: G Schett. Division of Rheumatology, Department of \\ Internal Medicine III, University of Vienna, Währinger Gürtel 18-20, A-1090 \\ Vienna, Austria. Tel: + 43-1-40400-4300; Fax: + 431-40400-4306; \\ E-mail: georg.schett@akh-wien.ac.at
}

Received 19.2.03; accepted 22.4.03

Edited by RA Knight

\begin{abstract}
TNF $\alpha$ uniquely combines proinflammatory features with a proapoptotic potential. Activation of HSF1 followed by induction of hsp70 is part of a stress response, which protects cells from apoptosis. Herein, the effects of TNF $\alpha$ on the hsp70 stress response were investigated. TNF $\alpha$ caused transient downregulation of HSF1 activation and hsp70 synthesis, leading to increased sensitivity to heat-induced apoptosis. Blockade of TNF-R1, but not TNF-R2, as well as inhibition of protein phosphatases PP1/PP2a and PP2b completely blocked this effect. In contrast, blockade of MAPK/SAPK-, NF- $\kappa$ B (NF-kappaB)-, and PKC- pathways as well as the caspase cascade did not prevent downregulation of HSF $1 / h s p 70$. These data demonstrate that TNF $\alpha$ transiently inhibits the hsp70 stress response via TNF-R1 and activation of protein phosphatases. The price of inhibition of an essential cellular stress response is increased sensitivity to apoptotic cell death.

Cell Death and Differentiation (2003) 10, 1126-1136. doi:10.1038/ sj.cdd. 4401276
\end{abstract}

Keywords: tumor necrosis factor; heat shock proteins; apoptosis; protein phosphatases

Abbreviations: EMSA, electrophoretic-mobility shift assay; ERK, extracellular signal-related kinase; HSF, heat shock factor; hsp, heat shock protein; JNK, C-jun N-terminal kinase; MAPK/ SAPK, mitogen-/stress-activated protein kinases; NF- $\kappa$ B (NFkappaB), nuclear factor kappaB; PKC, protein kinase C; PP, protein phosphatase; TNF, tumor necrosis factor; TNF-R, tumor necrosis factor receptor; TUNEL, terminal deoxynucleotidyl transferase-mediated dUTP nick end labeling

\section{Introduction}

Tumor necrosis factor alpha (TNF $\alpha$ ) elicits a broad spectrum of cellular and organismal responses including cell proliferation and differentiation, inflammation and apoptosis. ${ }^{1}$ Binding of TNF $\alpha$ to its two receptors, TNF-R1 and TNF-R2, results in a complex and not yet fully elucidated cascade of signaling steps finally leading to the activation of at least three distinct effector pathways. ${ }^{2,3}$ Two of them recruit transcription factors, the AP-1 complex and NF-kappaB (NF- $\kappa \mathrm{B})$, that upon their activation induce genes mediating proliferative and inflammatory responses of TNF $\alpha^{4,5}$ The third, the caspase cascade, constitutes major effector molecules critically involved in apoptosis, thus mediating the opposite cellular response. ${ }^{6}$ Thereby, TNF $\alpha$ has a unique role in regulating a cells' choice between antiapoptotic signals, inducing cell proliferation and/or inflammation, and proapoptotic signals, inducing cell death.

Stress or heat shock proteins (hsp) constitute a phylogenetically old cellular system providing increased resistance to a variety of cellular stress factors, such as elevated temperatures, heavy metal ions, oxidants and amino-acid analog., Hsp70, one of the most widely and best studied forms of hsp in mammalian cells, is characterized by its highly inducible expression in response to stress and by its function as a chaperone, facilitating the folding, unfolding and refolding of proteins under both normal and stressful conditions., 9 Induced expression of hsp70 has been shown to promote cytoprotection. ${ }^{11,12}$ Stress-induced synthesis of hsp70 is regulated at the transcriptional level via the activation of heat shock transcription factors (HSF). ${ }^{7}$

The cytoprotective effect of hsp70 is partly based on its ability to impede apoptosis and experimental evidence suggests the cellular level of hsp70 as a critical parameter for cell survival and susceptibility to apoptosis. ${ }^{11,12-16}$ The efficacy of proapoptotic agents at least partly depends on the activation state of the HSF1/hsp70 system in the target cell. Indeed, some proapoptotic molecules have the ability to shut down a potentially conflicting HSF $1 /$ hsp70 stress response to facilitate the induction of apoptosis. For instance, induction of apoptosis by FasL leads to inhibition of HSF1 activation and hsp70 synthesis. ${ }^{17}$

It is unclear, whether TNF has the ability to impede antiapoptotic mechanisms, such as the HSF1/hsp70 stress response, and how such potential effects may influence susceptibility to apoptosis. The data obtained in this study show that TNF $\alpha$ transiently downregulates the hsp70 stress response. This effect is accomplished by TNF-R1- and protein phosphatase-mediated inhibition of HSF1 phosphorylation and leads to increased sensitivity to apoptosis. 


\section{Results}

\section{TNF $\alpha$ induces a transient decrease of HSF1-DNA binding}

To address whether TNF $\alpha$ can interfere with heat-induced activation of HSF1, we performed EMSA analysis of HSF1binding to DNA after sequential treatment of cells with TNF $\alpha$ and heat stress. Cells were first treated with TNF $\alpha$ and then exposed to heat stress after various periods of time. Untreated control cells and cells treated with TNF $\alpha$ alone did not show relevant activation of HSF1 (Figure 1). In contrast, heat stress lead to a dramatic (up to 24-fold) activation of HSF1. Supershift analysis using Mab to either HSF1 or HSF2 confirmed the oligonucleotide-protein complexes to contain HSF1, and not HSF2. Simultaneous treatment with heat and $\mathrm{TNF} \alpha$ did not alter the responsiveness of cells to heat stress.

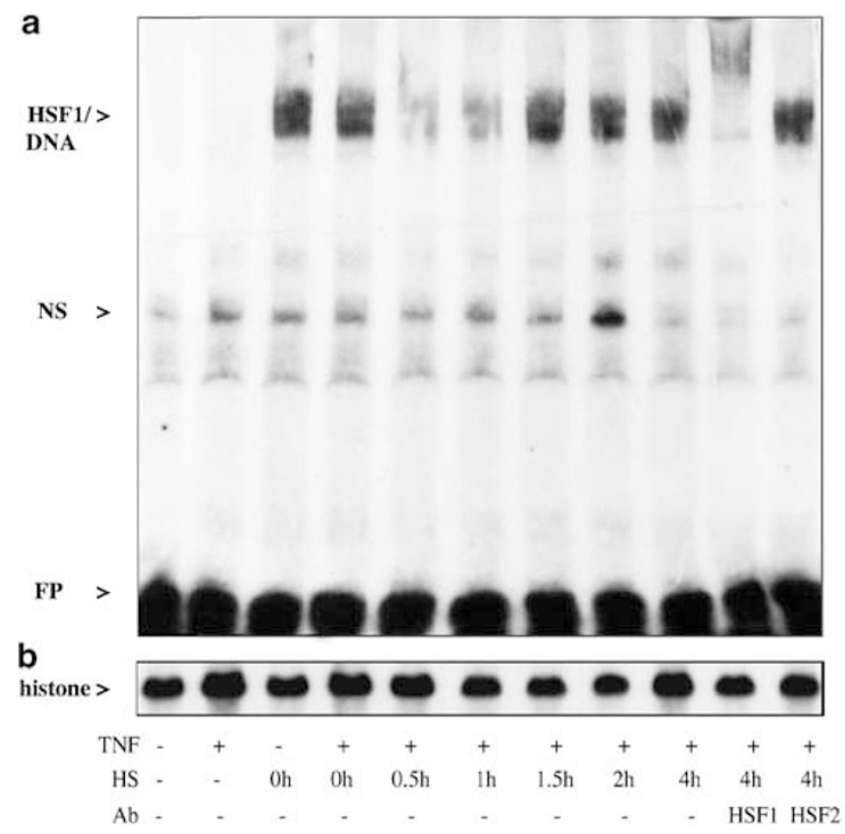

C

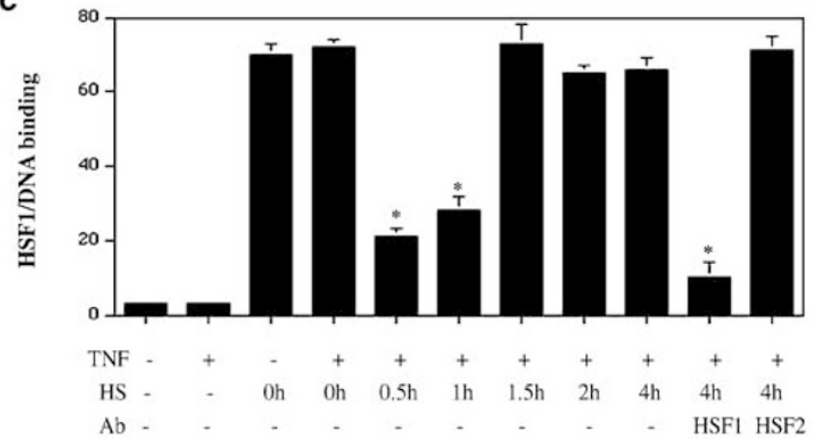

Figure 1 TNF $\alpha$ induces a transient decrease of heat-induced binding of HSF1 to DNA. (a) EMSA of HSF1 binding to DNA. Cells were first treated with TNF $\alpha$ followed by heat stress (HS) after various periods of time $(0-4 \mathrm{~h})$. Supershift analysis with anti-HSF1 or anti-HSF2 Ab revealed the presence of HSF1 in protein/DNA complexes. HSF1: HSF1/DNA complexes, NS: nonspecific band, FP: free probe; (b) immunoblotting of histone $\mathrm{H} 1$ used as protein loading control (c) quantitative data analysis by Phospholmager (relative Phospholmager units) showing mean \pm s.e. values of three individual experiments. Asterisks indicate significant difference to heat-stressed cells $(P<0.01)$
However, when heat stress was applied only 30 min after TNF $\alpha$, a significant $(P<0.01)$, up to $70 \%$, inhibition of heat-induced HSF1 -binding to DNA was evident, suggesting an inhibitory role of TNF $\alpha$ on HSF1 activation. Interestingly, this inhibition was of transient nature and not observed when cells were heat stressed more than $1 \mathrm{~h}$ after TNF $\alpha$ treatment. Thus, binding of HSF1 in cells subjected to heat stress more than $1 \mathrm{~h}$ after TNF treatment did not differ from that induced by heat stress alone (Figure 1).

\section{TNF $\alpha$ decreases phosphorylation and nuclear translocation of HSF1 and inhibits hsp70 synthesis}

To address whether decreased DNA binding of HSF1 is due to inhibition of hyperphosphorylation and nuclear translocation of HSF1, immunoblot analyses of total and nuclear HSF1 levels were performed. In addition, immunoprecipitates of HSF1 were analyzed for serine phosphorylation. Furthermore, expression of the effector molecule (hsp70) was investigated. Untreated and TNF $\alpha$-treated cells did not reveal relevant activation of the HSF/hsp70 axis, thus showing only weak hyperphosphorylation (Figure 2a, lanes 1 and 2), serine phosphorylation (Figure 2b, lanes 1 and 2) and nuclear translocation of HSF1 (Figure 2c, lanes 1 and 2). Also, binding of HSF1 to DNA (Figure 2d, lanes 1 and 2) and the cellular expression of hsp70 were low (Figure 2e, lanes 1 and 2). In contrast, heat stress led to hyperphosphorylation, serine phosphorylation and increased nuclear expression (due to translocation) of HSF1 (Figure 2a-c, lane 3). However, pretreatment with $\mathrm{TNF} \alpha, 30 \mathrm{~min}$ before application of heat stress, significantly $(P<0.01)$ inhibited hyperphosphorylation, serine phosphorylation and nuclear translocation of HSF1 (Figure 2a-c, lane 4) and thus blocked upregulation of hsp70 (Figure 2e, lane 4). To investigate whether TNF $\alpha$-mediated inhibition of HSF1 activation may be influenced by previous heat exposure, cells were heat stressed $12 \mathrm{~h}$ before the sequential stimulation with TNF $\alpha$ and exposure to heat stress. These cells also displayed blunted HSF1 activation upon heat treatment (Figure $2 a-d$, lane 5), although hsp70 was still upregulated due to the previous exposure to heat (Figure $2 \mathrm{e}$, lane 5).

\section{TNF $\alpha$ sensitizes cells for heat-induced apoptosis}

To evaluate whether transient downregulation of the HSF1/ hsp70 stress response leads to increased susceptibility to apoptosis, the effect of TNF $\alpha$ treatment on heat-induced apoptosis was investigated. Apoptosis rates were analyzed $5 \mathrm{~h}$ after the end of heat stress by annexin $\mathrm{V}$ and TUNEL staining. Basal apoptosis rates were low and amounted to 2$4 \%$ of total cells (Figure 3a, b). Treatment with TNF $\alpha$ alone did not entail a significant increase of apoptosis rates and single treatment with heat stress only weakly increased apoptosis rates above basal levels. However, heat stress applied after $\mathrm{TNF} \alpha$ treatment, strongly increased susceptibility to heatinduced apoptosis when applied between $30 \mathrm{~min}$ and $1 \mathrm{~h}$ after $\mathrm{TNF} \alpha$ treatment, corresponding to the time window of TNF $\alpha$ mediated inhibition of HSF1 (see Figure 1). Thus, apoptosis 


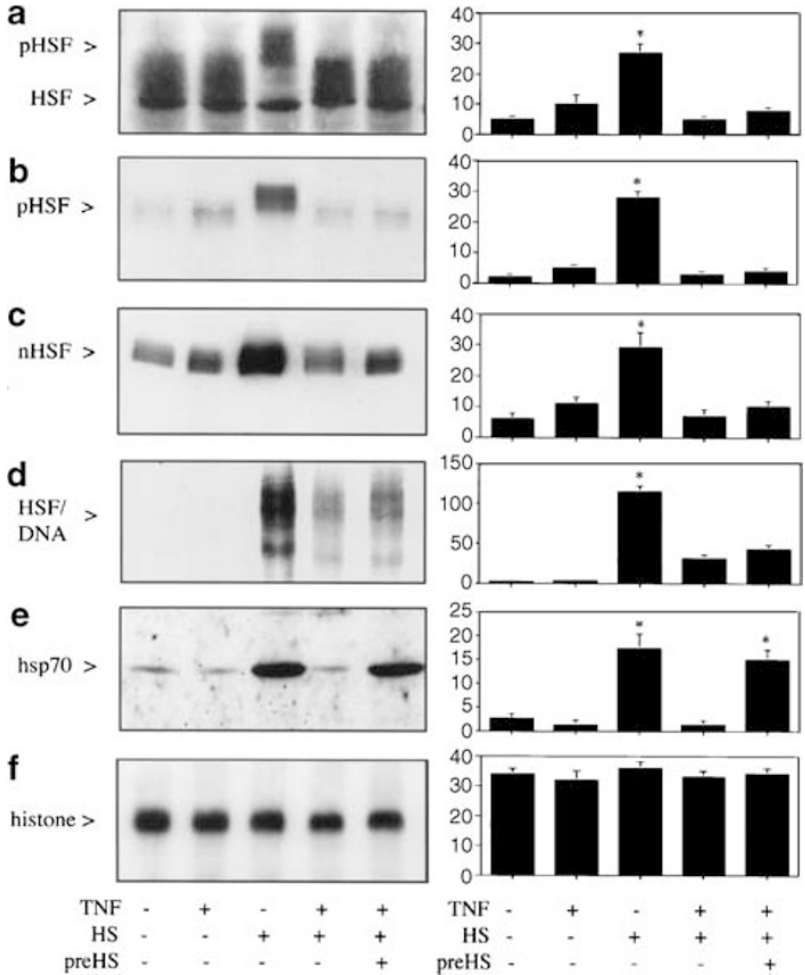

Figure 2 TNF $\alpha$ inhibits phosphorylation, nuclear translocation and DNA binding of HSF1 and blocks hsp70 synthesis. Cells were treated with TNF $\alpha$ and/ or heat stress (HS). For sequential treatment, TNF $\alpha$ was applied $30 \mathrm{~min}$ before heat stress. Previous heat stress (Pre-HS) indicates exposure to heat stress $12 \mathrm{~h}$ before TNF $\alpha$ treatment. (a) Western blot of HSF1 showing hyperphosphorylation of HSF1 (pHSF) as indicated by a band shift to higher molecular isoforms of HSF1 (lane 3). (b) Western blot of precipitates of HSF1 probed with antiphosphoserine antibody indicating inducible serine phosphorylation. (c) Western blot analysis of HSF1 in nuclear extracts indicating nuclear translocation (nHSF). (d) EMSA indicating HSF1 binding to DNA; (e) Western blot of hsp70. (f) Immunoblotting of histone $\mathrm{H} 1$ used as protein loading control. The right columns show quantitative data analysis by Phospholmager (relative Phospholmager units). Values represent mean \pm s.e. of three individual experiments; asterisks indicate significant differences to untreated control cells $(P<0.01)$

rates significantly $(P<0.05)$ increased to $25 \%$ (annexin $\mathrm{V})$ and $18 \%$ (TUNEL), respectively. In contrast, heat stress applied before TNF $\alpha$, at the same time with TNF $\alpha$, or up to15 min after $\mathrm{TNF} \alpha$, did not change apoptosis rates. Also, when cells were heat stressed later than $1 \mathrm{~h}$ after $\mathrm{TNF} \alpha$ no significant increase in apoptosis rates was observed.

\section{TNF $\alpha$ increases susceptibility to heat-induced apoptosis in a time- and concentration-dependent manner}

To investigate the role of TNF $\alpha$ on heat-induced apoptosis and hsp70 expression in more detail, a time- and concentrationdependent analysis was carried out. Heat stress induced a rapid upregulation of hsp70 levels with up to 90\% hsp70positive cells after $10 \mathrm{~h}$ (Figure 4a). Relevant (>10\%) apoptosis or cell death did not occur. However, when TNF $\alpha$ treatment preceded heat stress (Figure 4b), the hsp70 response was strongly inhibited and after $10 \mathrm{~h}$ less than
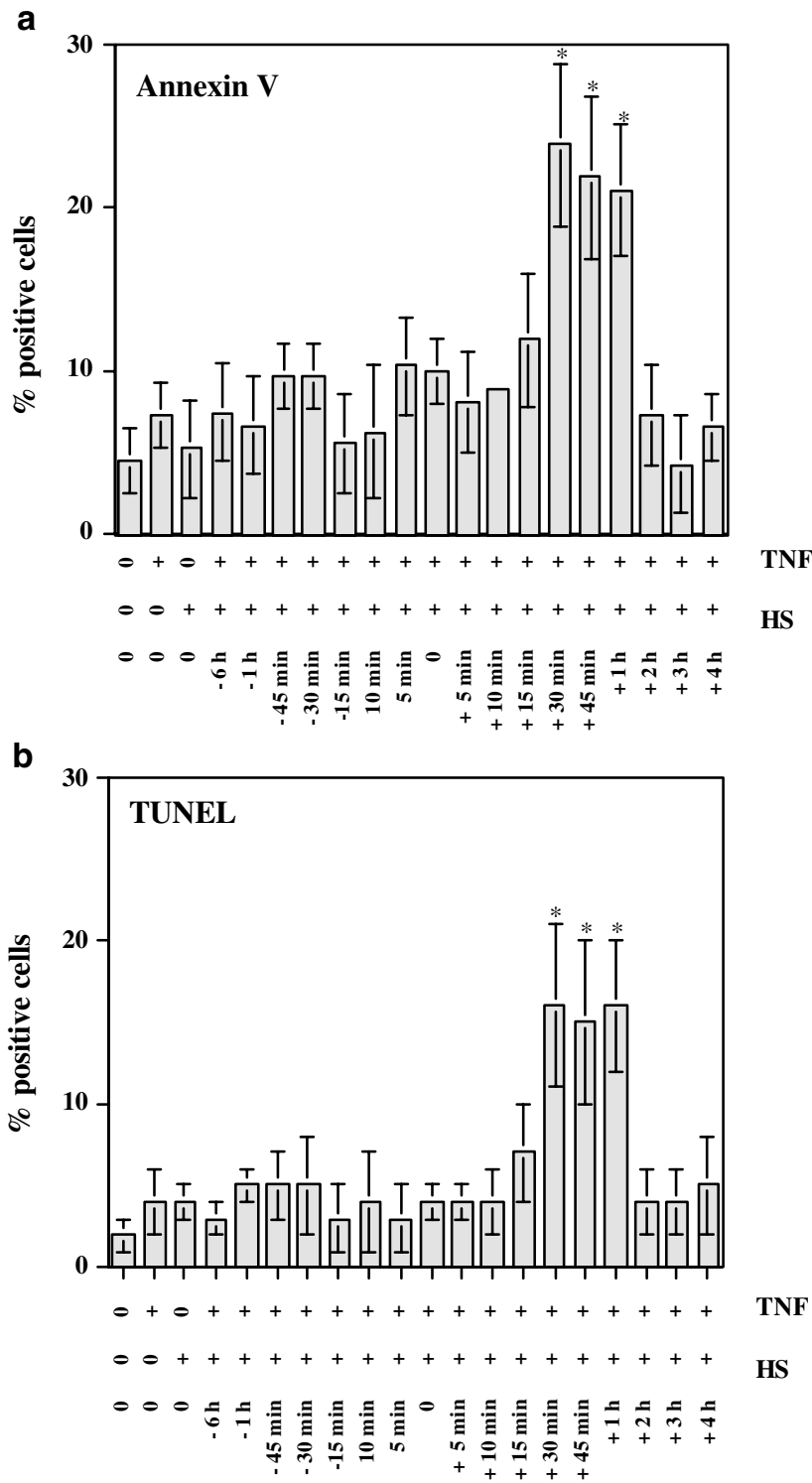

Figure 3 Transient inhibition of HSF $1 /$ hsp70 is associated with an increased susceptibility to heat-induced apoptosis. Cells were sequentially treated with TNF $\alpha$ and HS. HS was applied from $6 \mathrm{~h}$ before to $4 \mathrm{~h}$ after TNF $\alpha$ stimulation. (a) Percentage of annexin V-positive cells; (b) percentage of TUNEL-positive cells by FACS analysis. Note the increased apoptosis rate during the time interval of decreased HSF1/hsp70 activation. Data are mean \pm s.e. of three individual experiments. $Y$-axis: percent of positive cells. Asterisks indicate significant differences to heat-stressed cells $(P<0.01)$

$25 \%$ of cells expressed hsp70. Apoptosis rates on the other hand rapidly and significantly $(P<0.01)$ increased up to $25 \%$ $5 \mathrm{~h}$ and up to $70 \% 10 \mathrm{~h}$ after heat stress, reflecting inhibition of the HSF1/hsp70 stress response. The number of propidium iodide (PI)-positive cells remained low and was similar to that found with isolated heat stress, indicating that cell necrosis was not a confounding variable in these experiments. To address the influence of pre-existing hsp70 upregulation, the same analysis was performed with cells that had been subjected to heat stress $12 \mathrm{~h}$ before TNF $\alpha$ treatment. As expected, expression of hsp70 was abundant and remained 

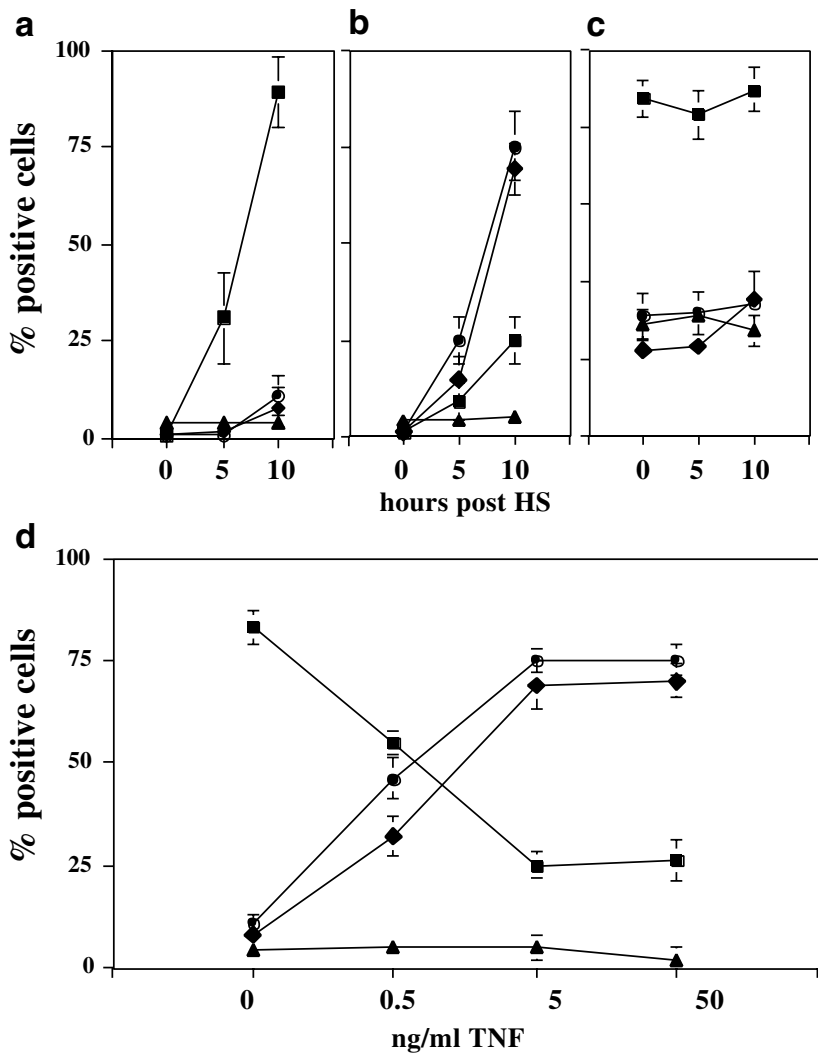

Figure 4 Inhibition of HSF1/hsp70 and increased apoptosis mediated by TNF $\alpha$ is time- and dose-dependent. Cells were treated with (a) HS, (b) TNF $\alpha 30$ min before HS or (c) TNF $\alpha 30 \mathrm{~min}$ before HS under conditions of hsp70 overexpression (pre-HS $12 \mathrm{~h}$ before TNF $\alpha$ addition). Cells were assessed for annexin V $(\boldsymbol{\bullet})$, TUNEL $(\bullet)$, PI $(\boldsymbol{\Delta})$ - and hsp70 ( $\mathbf{\square})$ by FACS. Analysis was performed after 0,5 and $10 \mathrm{~h}$. (d) Cells were treated with $0,0.5,5$ and $50 \mathrm{ng} / \mathrm{ml}$ $\mathrm{TNF} \alpha$, respectively $30 \mathrm{~min}$ before $\mathrm{HS}$. Cells were analyzed by annexin $\mathrm{V}$ staining $(\boldsymbol{\bullet})$, TUNEL assay $(\boldsymbol{\bullet}), \mathrm{PI}(\boldsymbol{\Lambda})$ and hsp70 ( $)$. Data are mean \pm s.e. of three individual experiments. $Y$-axis: percent of positive cells

unchanged throughout the experiment (Figure 4c). Apoptosis rates, however, were significantly lower (25 versus $70 \%$, $P<0.01)$ and did not increase throughout the experiment, suggesting that hsp70 protected cells from this permissive proapoptotic effect of $\mathrm{TNF} \alpha$. The observation of slightly elevated basal levels of apoptotic and dead cells in this setting can be explained by assuming that previous heat stress (applied $12 \mathrm{~h}$ before TNF $\alpha$ ) had led to a limited degree of apoptosis and cell death. Dose-response analyses revealed low concentrations $(0.5 \mathrm{ng} / \mathrm{ml})$ of $\mathrm{TNF} \alpha$ as sufficient to significantly repress the HSF1/hsp70 axis and allow heatinduced apoptosis (Figure 4d). This effect reached a plateau at a dose of $5 \mathrm{ng} / \mathrm{ml} \mathrm{TNF} \alpha$.

\section{Extracellular hsp70 negatively regulates HSF1 by inducing TNF production}

Based on the observation that hsp70 negatively regulates $\mathrm{HSF} 1^{18}$ and that extracellular hsp70 can induce TNF, ${ }^{19}$ we hypothesized that extracellular hsp70 acts on HSF1 via TNF. To prove this hypothesis, we incubated cells with hsp70 and screened supernatants for TNF production (Figure 5). Hsp70, a

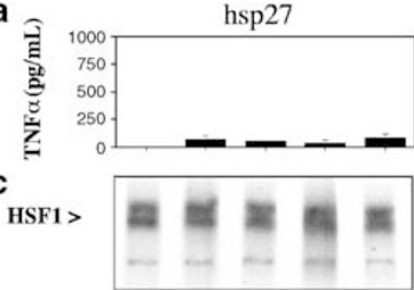

e hsp70>

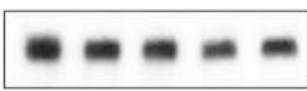

g

histone >
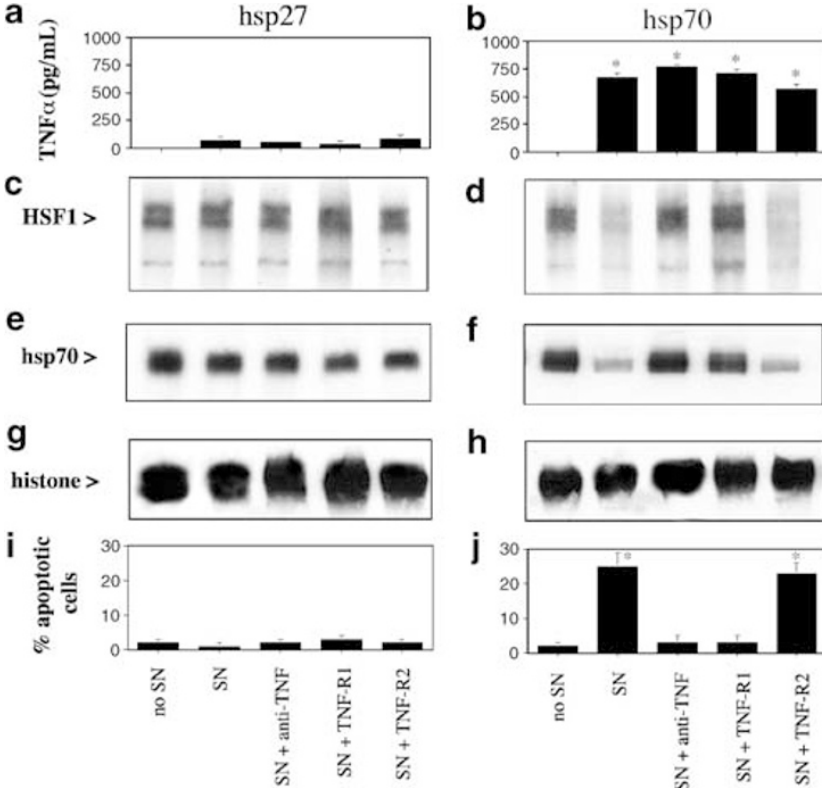

f

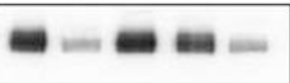

h
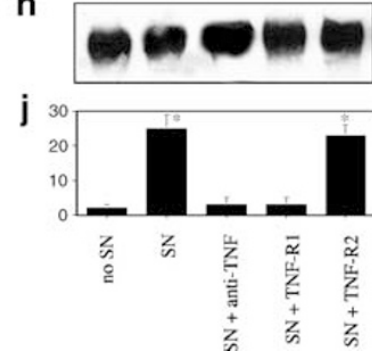

Figure 5 Hsp70 regulates the heat shock response by inducing TNF. Cells were treated with human $0.5 \mu \mathrm{M}$ hsp27 (left), as a control, or $0.5 \mu \mathrm{M}$ hsp70 (right). TNF production (a,b) was measured by ELISA after 3 days of culture. Supernatants (SN) were then incubated with fresh cells and cells were heat stressed after $30 \mathrm{~min}$. Incubations were performed with medium alone, as well as with blocking antibodies against TNF (anti-TNF), TNF-R1 and TNF-R2. Cells were then analyzed for HSF1/DNA binding (c,d) and hsp70 expression (e,f). Immunoblotting of histone $\mathrm{H} 1$ was used as protein loading control $(\mathbf{g}, \mathbf{h})$. Apoptosis rates (number of apoptotic cells) were measured by FACS using TUNEL technique $(\mathbf{i}, \mathbf{j})$. Note that TNF-containing supernatants inhibit the HSF1/ hsp70 stress response followed by increased apoptosis rates. Data are mean \pm s.e. of three individual experiments. $Y$-axis: percent of positive cells. Asterisks indicate significant differences to heat-stressed cells $(P<0.01)$

but not control protein (hsp27), induced significant production of TNF, as detected by measuring TNF levels in culture supernatants (Figure 5a,b). TNF-containing, but not control supernatants, significantly blocked HSF1 activation and hsp70 synthesis when incubated with fresh cells, which received heat shock $30 \mathrm{~min}$ after addition of the supernatant (Figure 5 c,d). Inhibition of HSF1/hsp70 was associated with significantly increased apoptosis rates (Figure $5 \mathrm{i}, \mathrm{j}$ ). Addition of anti-TNF antibody or blocking antibodies against TNF-R1, but not TNF-R2, reversed these effects, suggesting it to be mediated by TNF-TNFR1 interaction. In contrast, supernatants of cells stimulated with the control protein hsp27, containing only low levels of TNF, did not show any effects on HSF1/hsp70 and/or apoptosis (Figure 5c,e,i).

\section{Decreased HSF1 activation and hsp70 expression after TNF $\alpha$ treatment is TNF-R1- and protein phosphatase-dependent}

To elucidate the signaling pathway involved in $\operatorname{TNF} \alpha-$ mediated downregulation of HSF1, several key steps of TNF signaling were blocked by addition of specific inhibitors. These included blocking antibodies against TNF-R1 and -R2 as well as blockers of the MAPK/SAPK pathway, the caspase 
cascade, NF- $\kappa \mathrm{B}$ (NF-kappaB), PKCs and protein phosphatases. Each inhibitor was added $1 \mathrm{~h}$ before stimulating the cells with $T N F \alpha$ and thus $1.5 \mathrm{~h}$ before application of heat stress. At the end of heat exposure, binding of HSF1 to DNA was analyzed by EMSA. As shown before, binding of HSF1 to DNA was significantly (up to $80 \%$ ) inhibited in cells undergoing sequential stimulation with TNF $\alpha$ and heat stress (Figure 6a,b) as compared to cells exposed to heat stress alone. When blocking Ab to TNF-R1 was added, cells were able to maintain a normal responsiveness of HSF1 DNA binding in response to heat. These data indicate that TNF $\alpha$ mediates its suppressive effect on the HSF1/hsp70 axis via TNF-R1 signaling. In contrast, blockade of TNF-R2 was not effective. More downstream, none of the major kinase-signaling pathways of TNF $\alpha$ appeared to be involved in the inhibition of HSF1: selective interference with MAPK/SAPK-, NF- $\kappa \mathrm{B}$ - and PKC-signaling pathways was unable to maintain a normal responsiveness of HSF1 to heat stress. Moreover, inhibition of ERK and NF- $\kappa \mathrm{B}$ signaling even led to an additional suppression of HSF1 responsiveness, by downregulating HSF1-DNA binding to the level of untreated control cells. In contrast, inhibition of protein phosphatases PP1/2a (by okadaic acid) and PP2b (by FK506) completely rescued HSF1-DNA binding, suggesting PPs to function as essential mediators of TNF-induced inhibition of HSF1.

The data on HSF1-DNA binding were mirrored by hsp70 expression as assessed by FACS analysis. Heat-induced hsp70 expression was significantly $(P<0.01)$ blocked by TNF $\alpha$ (13 versus $48 \%$ positive cells compared to heat stress alone; Figure $6 \mathrm{~d}$ ) and was not altered by blocking those pathways apparently ineffective to reverse HSF1 inhibition (TNF-R2, caspases, PKCs, JNK and p38). Blockade of TNF-R1 as well as PP1/PP2a and PP2b, however, maintained hsp70 expression. In contrast, blockade of $\mathrm{ERK}$ and $\mathrm{NF}-\kappa \mathrm{B}$ signaling severely interfered with hsp70 upregulation; despite heat stress, the number of cells expressing hsp70 was extremely low (3\% with ERK-blockade, $2 \%$ with NF- $\kappa$ B blockade; $P<0.01$ compared to TNF $\alpha$ and heat stress). Thus, these data not only show that TNF $\alpha$-mediated inhibition of the HSF1/ hsp70 axis depends on TNF-R1 and PPs, but also suggest that functional ERK and $N F-\kappa B$ signaling is required for the maintenance of an adequate stress response.

\section{TNF $\alpha$ mediates susceptibility to heat-induced apoptosis via TNF-R1 and protein phosphatases}

To investigate whether this signaling pathway was also involved in rendering cells susceptible to heat-induced apoptosis, apoptosis rates were analyzed. As described above, pretreatment with TNF $\alpha$ entailed increased susceptibility to heat-induced apoptosis and hampered hsp70 expression. Thus, after $5 \mathrm{~h}$, the rates of annexin $\mathrm{V}$ - and TUNEL-positive cells were significantly $(P<0.01)$ increased (32 and 29\%, respectively) as compared to heat stress alone (11 and 4\%, respectively) (Figure 7a, b). Addition of neutralizing $\mathrm{Ab}$ against TNF-R1 completely blocked these effects (12\% annexin V-positive cells; $3 \%$ TUNEL-positive cells), suggesting suppressed hsp70 expression and increased heat-induced apoptosis to be mediated through its binding to TNF-R1. Again, blockade of TNF-R2 proved
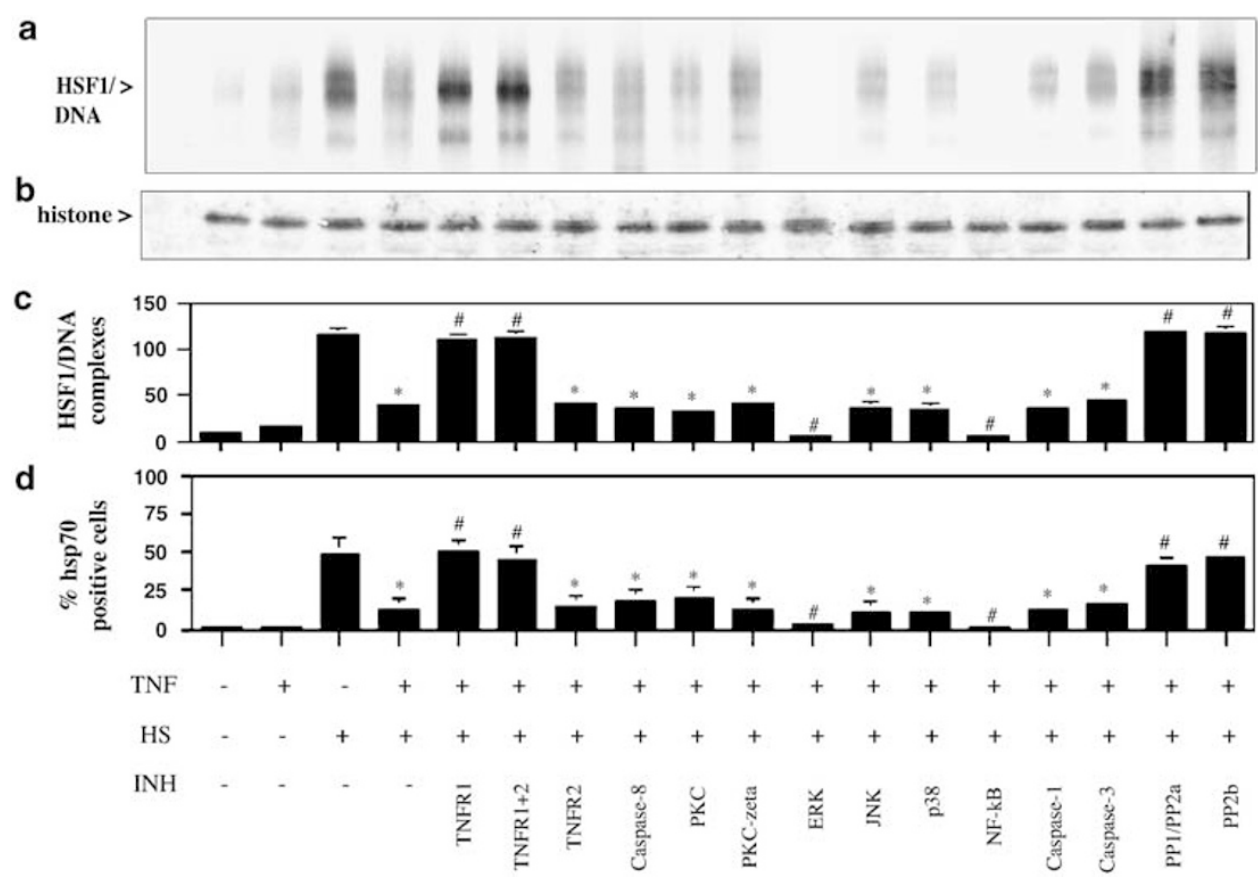

Figure 6 TNF $\alpha$-mediated inhibition of HSF1/hsp70 is TNF-R1- and protein phosphatase-dependent and signaling via ERK and NF- $\kappa$ B is critical for the activation of HSF1/hsp70. TNF $\alpha$-signaling pathways were blocked by specific inhibitors (INH) in cells sequentially treated with TNF $\alpha$ and HS. (a) EMSA analysis of HSF1; (b) immunoblotting of histone $\mathrm{H} 1$ used as protein loading control; (c) quantitative data analysis by Phospholmager (relative Phospholmager units; mean \pm s.e. of three independent experiments); (d) FACS analysis of hsp70 expression (mean + s.e. of three individual experiments; $Y$-axis: percent of positive cells). Note the normal HSF1/ DNA binding and hsp70 expression during blockade of TNF-R1 and protein phosphatases PP1/PP2a and PP2b and a complete inhibition of HSF1/hsp70 when ERKand NF- $\kappa$ B pathways were blocked. Asterisks indicate significant differences to heat-stressed cells $(P<0.01)$; \# indicates significant differences to cells treated with TNF + HS $(P<0.01)$ 
a

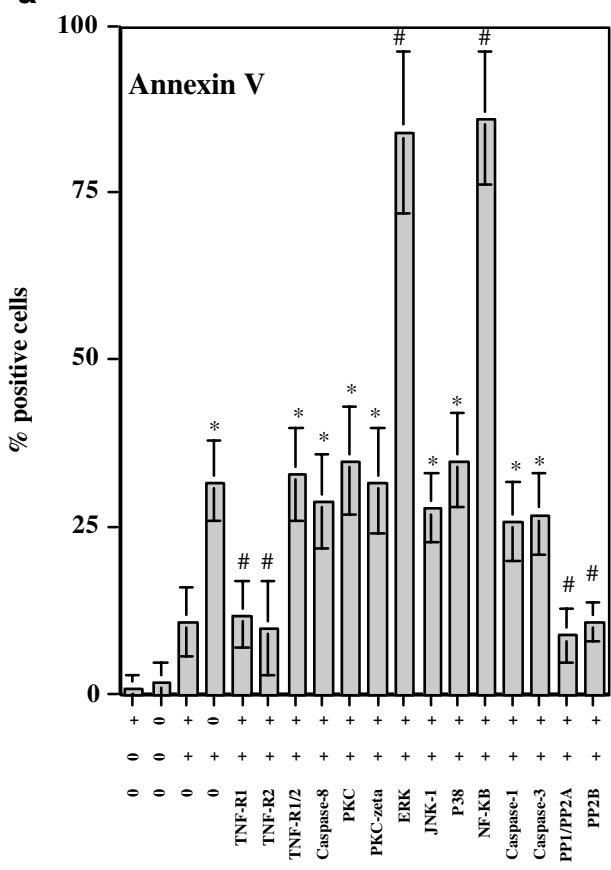

b

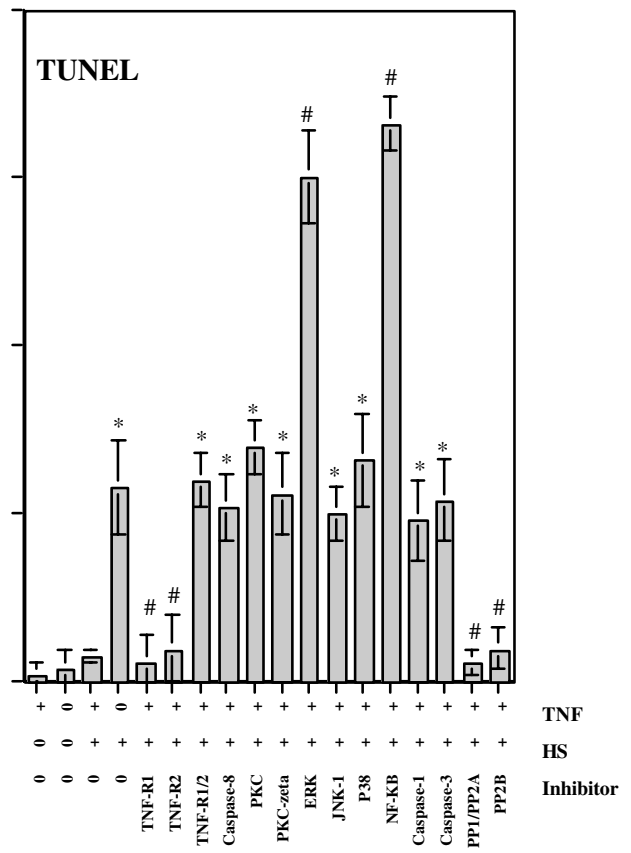

Figure 7 TNF $\alpha$-induced susceptibility to apoptosis is TNF $\alpha$ R1- and protein phosphatase-dependent and increased upon ERK and NF- $\kappa$ B blockade. Cells were sequentially treated with $\mathrm{TNF} \alpha$ and HS during a selective blockade of TNF $\alpha$ signaling pathways by specific inhibitors (INH). Apoptosis was assessed by annexin $\mathrm{V}$ (a) and TUNEL staining (b). Note the resistance to apoptosis when blocking TNF-R1, protein phosphatases, PP1/PP2a and PP2b, despite sequential stimulation with TNF $\alpha$ and $\mathrm{HS}$ as well as high apoptosis rates when ERK and NF- $\kappa$ B pathways were inhibited. Data are mean \pm s.e. of three individual experiments. $Y$-axis: percent of positive cells. Asterisks indicate significant differences to heat-stressed cells $(P<0.01)$; \# indicates significant differences to cells treated with TNF + HS $(P<0.01)$

ineffective. Among the more downstream signaling molecules, only the inhibition of PPs, PP1/PP2a and PP2b effectively prevented susceptibility to heat-induced apoptosis (PP1/PP2a: 9\% annexin V-positive, 3\% TUNEL-positive cells; PP2b: 11\% annexin V-positive, 5\% TUNEL-positive cells; $P<0.01$ compared to TNF $\alpha$ and heat stress). In accordance with the results from HSF1 activation and hsp70 expression, inhibition of p38, JNK, PKC, PKC $\zeta$, and caspases 1, 3 and 8 did not significantly influence apoptosis rates. In contrast, blockade of ERK and NF- $\kappa \mathrm{B}$ pathways led to a further dramatic increase in apoptosis rates: upon ERK blockade, the number of annexin-positive cells significantly increased to $84 \%$ and the number of TUNEL-positive cells to $75 \%(P<0.01$ compared to TNF $\alpha$ and heat stress). Upon NF- $\kappa$ B blockade, $86 \%$ of the cells were annexin positive and $83 \%$ were TUNEL positive $(P<0.01$ compared to TNF $\alpha$ and heat stress). These data demonstrate a direct link between increased susceptibility to apoptosis and inhibition of HSF $1 /$ hsp70 stress response by TNF-R1 and protein phosphatase signaling. Furthermore, intact NF- $\kappa \mathrm{B}$ and ERK signaling may negatively regulate this mechanism.

\section{Apoptosis is restricted to cells with a suppressed upregulation of hsp70}

To further address the link between the ability of a cell to upregulate hsp70 and its susceptibility to apoptosis, doublelabeling experiments for hsp70 and by TUNEL were carried out. For control purpose, apoptosis was further assessed by an additional double staining with annexin $\mathrm{V}$ and $\mathrm{PI}$. Five different treatments are shown in Figure 8: TNF $\alpha$ treatment alone left virtually all cells viable, as indicated by the large amount of annexin/PI double-negative cells (96\%; Figure 8a, red) and the very low number of TUNEL-positive cells after $5 \mathrm{~h}$ ( $1 \%$; Figure $8 \mathrm{~b}$ green/orange). In addition, the vast majority of cells were hsp70-negative (99\%; Figure $8 \mathrm{~b}$ red/green). Heat stress alone led to a minimal increase in the number of apoptotic cells (11\%, Figure 8c green; and 9\%, Figure $8 d$ green/orange, respectively), the major consequence being strong upregulation of hsp70 (84\%; Figure 8d blue). Almost all hsp70-expressing cells were TUNEL negative (Figure $8 \mathrm{~d}$ ). Pretreatment with $\mathrm{TNF} \alpha$ and subsequent heat stress was followed by rapid induction of apoptosis, as indicated by an increase of annexin-positive/PI-negative cells (49\%; Figure $8 \mathrm{e}$ green) and TUNEL-positive cells (43\%; Figure 8 green/orange). Dead cells (annexin/PI double positive and annexin negative/PI positive) remained constant (4\%; Figure $8 \mathrm{e}$ orange/blue). When assessing hsp70 expression, only the viable cell fraction was hsp70 positive (44\%; Figure $8 f$ blue), whereas TUNEL-positive apoptotic cells were hsp70 negative (34\%; Figure $8 f$ green). These results were even more pronounced in the presence of ERK inhibition (Figure $8 \mathrm{~g}, \mathrm{~h}$ ). The number of apoptotic cells was dramatically increased and all apoptotic cells were hsp70 negative (91\%; Figure $8 \mathrm{~h}$ green). Inhibition of PP1/PP2a, in contrast, completely reversed the effects of TNF $\alpha$ on the hsp70 expression and apoptosis rates (Figure 8i,j) and yielded identical results as with heat stress alone. Thus, hsp70 protein was rapidly induced (89\%; Figure 8j blue) and apoptosis rate was low (8\%, 

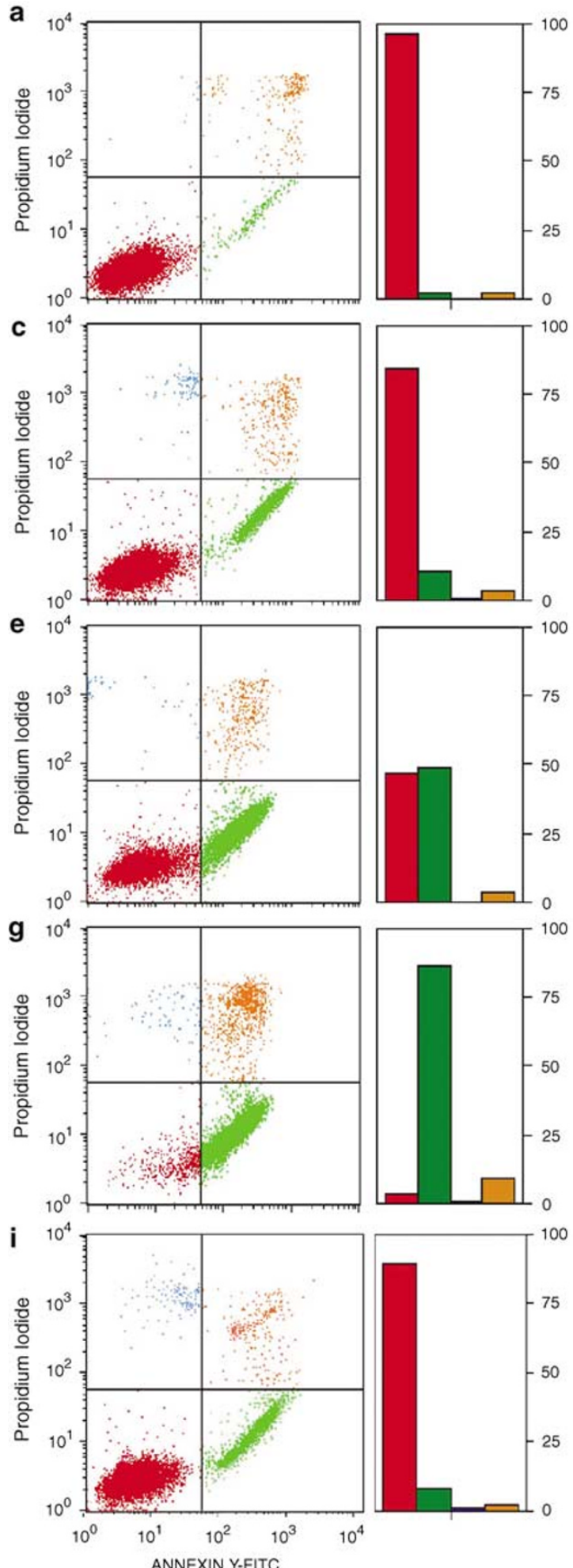

b
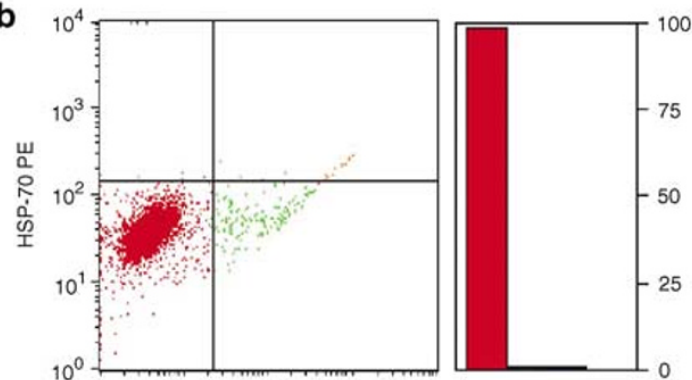

d
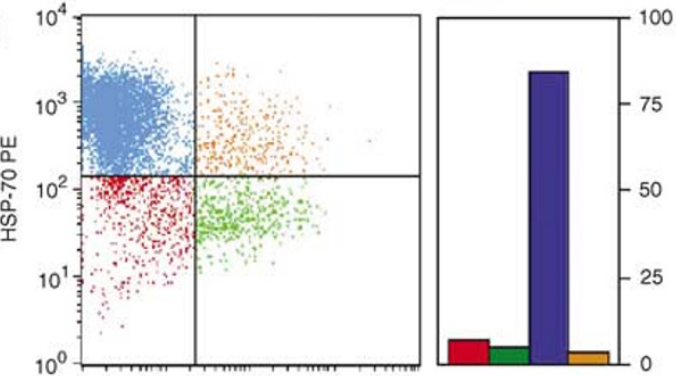

f
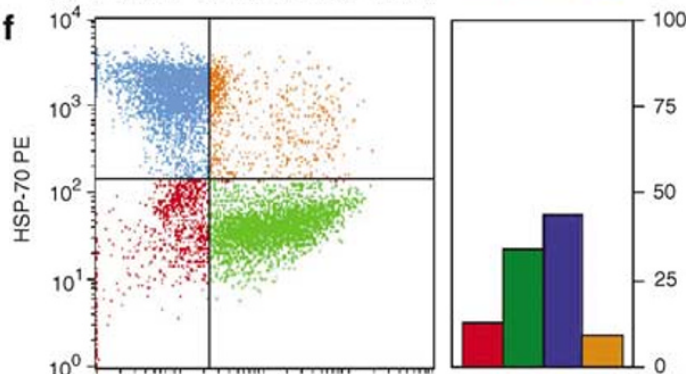

h
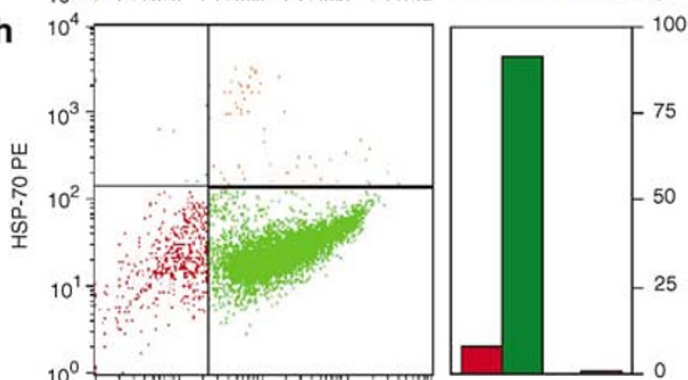

j

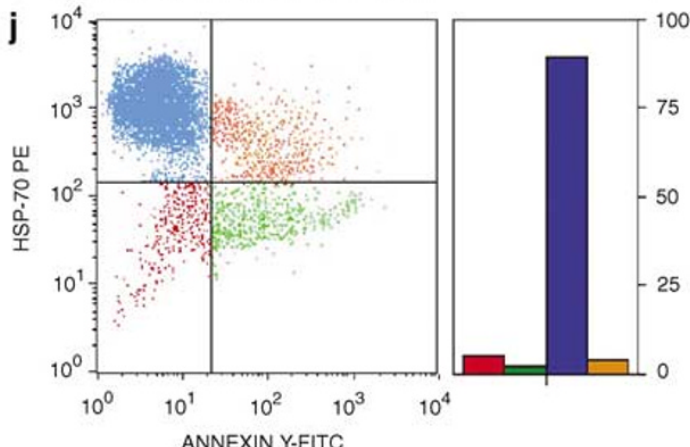

Figure 8 Inhibition of hsp70 expression is closely linked to apoptosis. Cells were treated with TNF $\alpha(\mathbf{a}, \mathbf{b}), \mathrm{HS}(\mathbf{c}, \mathbf{d}), \mathrm{TNF} \alpha 30 \mathrm{~min}$ before HS (e,f) or TNF $\alpha 30$ min before HS under conditions of ERK blockade (g,h) and PP1/PP2a blockade (i,j). (a,c,e,g,i) Double staining of annexin V and PI after $5 \mathrm{~h}$ : living (annexin/PI double negative, red), early apoptotic (annexin positive/PI negative, green), necrotic/dead (annexin negative/PI positive, blue), late apoptotic/dead (annexin/PI-double positive, orange); (b,d,f,h,j) double staining of TUNEL and hsp70 after $5 \mathrm{~h}$ : TUNEL/hsp70 double negative (red), TUNEL positive/hsp70 negative (green), TUNEL negative/hsp70 positive (blue), TUNEL/hsp70-double positive (orange). Representative data of three individual experiments are shown 
Figure $8 \mathrm{i}$ green; and 6\%, Figure 8j green/orange). Virtually identical results were obtained by inhbiting PP2b, yielding effective upregulation of hsp70 (88\%) and low apoptosis rates ( $9 \%)$. In summary, these data demonstrate that apoptosis was strictly confined to those cells displaying a suppressed HSF1/ hsp70 stress response.

\section{Discussion}

The data presented reveal that an important protective cellular activity, the HSF1/hsp70 stress response, is severely impeded by TNF $\alpha$. This effect is transient and leads to increased susceptibility towards heat-induced apoptosis. Interestingly, like apoptosis directly mediated by $\mathrm{TNF} \alpha$, downregulation of HSF1 induction is triggered by signaling via TNF-R1. More downstream, however, this effect involves protein phosphatases, PP1/PP2a and PP2b, which inhibit the phosphorylation and thus activation of HSF1 (Figure 9a).

Studies on the interplay between TNF $\alpha$ and hsps require to consider the dual role of this cytokine, which has the ability to induce inflammatory responses (Figure 9b, arrow a) and also has the potential to trigger apoptosis (Figure 9b, arrow b). The decisive steps, which allow TNF $\alpha$ to trigger apoptotic death in one cell but lead to inflammatory responses in another cell, have not been fully elucidated. ${ }^{2}$ However, it has become evident that the signaling pathway predominantly activated upon TNF $\alpha-T N F-R$ interaction is crucial for the downstream cellular response. Thus, signaling through ERK and NF- $\kappa \mathrm{B}$ pathways exclusively mediate inflammatory responses, but not TNF $\alpha$-mediated apoptosis. ${ }^{4,5}$ TNF $\alpha$ signaling via p38, JNK and atypical PKC also mediates inflammatory responses. ${ }^{5,20-}$ ${ }^{22}$ Although activation of p38 and JNK also has a proapoptotic potential, ${ }^{23,24}$ an essential role of TNF $\alpha$-mediated p38 or JNK signaling for induction of apoptosis has not yet been established. ${ }^{20}$ Furthermore, TNF $\alpha$-induced apoptosis is predominately dependent on TNF-R1 signaling ${ }^{25}$ and the activation of caspase-8 followed by the induction of effector caspases, such as caspase-3. ${ }^{26}$ Since deficiency of FADD, an essential link between TNF-R1 and caspase-8, does not completely abrogate TNF $\alpha$-induced apoptosis, other yet unidentified pathways have to be postulated. ${ }^{27}$ Some of these may involve the activation of protein phosphatases. ${ }^{28,29}$

Signals involved in inflammatory responses of TNF $\alpha$, such as NF- $\kappa \mathrm{B}$, suppress TNF $\alpha$-mediated apoptosis (Figure 9b; arrow $\mathrm{c}$ ) and thereby prevent a conflicting cellular response. 2,30 This concept of suppression of conflicting cellular responses is also applicable for the HSF1/hsp70 system. The antagonistic role of apoptotic mechanisms on the one hand, and resistance mechanisms, especially upregulation of heat shock protein, on the other hand is well known. The HSF1/ hsp70 stress response is the prototype of a stress-resistance mechanism. Thus, it aims to prevent apoptosis and indeed HSF1/hsp70 activation provides protection against a variety of proapoptotic stimuli. ${ }^{7,8}$ Most importantly, the proapoptotic effect of cytokines such as TNF $\alpha^{11}$ and FasL, ${ }^{17}$ which bind to the TNF-R superfamily, is inhibited by induction of HSF1/ hsp70 (Figure 9b, arrow d). Our own previous investigations on the interplay of Fas signaling and HSF1/hsp70 revealed that, vice versa, Fas, once activated, shuts down the HSF1/

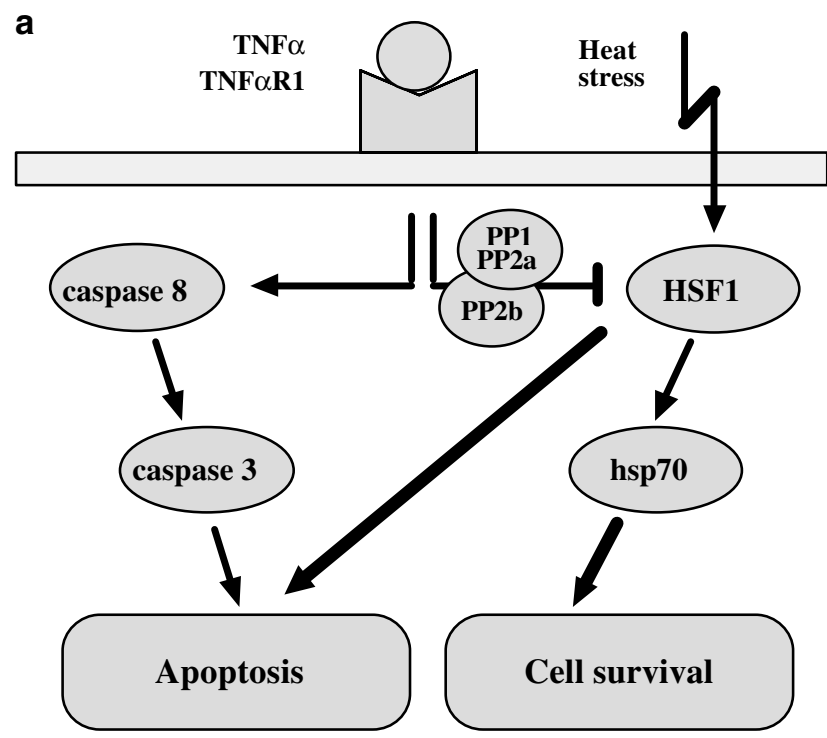

b

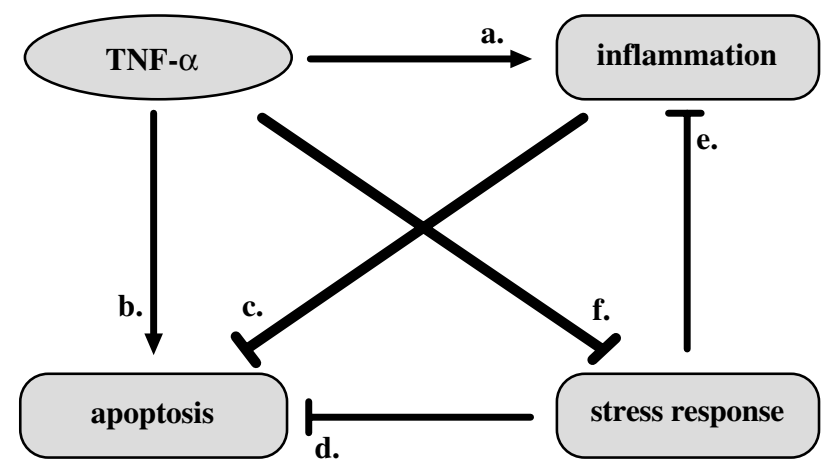

Figure 9 Schematic mechanism of TNF $\alpha$-mediated inhibition of HSF1/hsp70 and susceptibility to apoptosis. (a) The classical pathway of TNF $\alpha$-mediated apoptosis involves TNF-R1 activation and signaling through caspase-8, which subsequently activates effector caspases, such as caspase-3. TNF $\alpha$ inhibits the HSF1/hsp70 stress response via TNF-R1 and protein phosphatases PP1/PP2a and PP2b, which block the phosphorylation and thus activation of HSF1. A blocked HSF1/hsp70 axis renders a cell susceptible to heat-induced apoptosis. (b) Model of interplay between functional cellular responses, stress resistance and apoptosis upon stimulation with TNF $\alpha$. Cellular regulation of inflammatory responses, stress responses and apoptosis upon stimulation with TNF $\alpha$ : (a) TNF $\alpha$ stimulates inflammation, (b) TNF $\alpha$ stimulates apoptosis, (c) proinflammatory signaling inhibits apoptosis, (d) stress response inhibits apoptosis, (e) stress response inhibits proinflammatory signaling and (f) TNF $\alpha$ inhibits the stress response

hsp70 stress response and thereby inhibits a potential rescue of cells from apoptosis. ${ }^{17}$

In contrast to TNF $\alpha$, Fas is mainly linked to apoptosis and does not usually entail inflammatory or proliferative responses. Such responses, however, have to be considered when investigating the interaction of $\mathrm{HSF} 1 / \mathrm{hsp} 70$ with TNF $\alpha$ mediated processes. Several pieces of evidence suggest a suppressive role of $\mathrm{HSF} 1 / \mathrm{hsp} 70$ on TNF $\alpha$-triggered inflammatory responses (Figure 9b, arrow e). Thus, activation of HSF1/hsp70 inhibits NF- $\kappa$ B activation ${ }^{31-33}$ as well as transcription of the TNF $\alpha$ gene ${ }^{34}$ and LPS-mediated induction of 
TNF $\alpha .{ }^{35}$ Furthermore, HSF1-deficient (-/-) mice show a deregulated TNF $\alpha$ production and increased mortality after endotoxin challenge. ${ }^{36}$ These data suggest that cell-survival mechanisms, such as HSF $1 /$ hsp 70 induction, enable a downregulation of inflammatory responses when conditions are harsh.

Based on the fact that an activated HSF1/hsp70 system exerts an inhibitory function on both TNF $\alpha$-mediated inflammatory responses and TNF $\alpha$-mediated apoptotic death, the inhibition of HSF1/hsp70 activation by TNF $\alpha$, observed in our study is highly conceivable (Figure $9 b$, arrow f). Thus, TNF $\alpha$ ensures an undisturbed completion of cellular responses, either proinflammatory or apoptotic, by shutting down an inhibitory and therefore potentially conflicting pathway, such as $\mathrm{HSF} 1 / \mathrm{hsp} 70$. TNF $\alpha$-mediated inhibition of HSF $1 /$ hsp70 occurs fast and thus relieves both inflammatory and apoptotic pathways from a suppressive factor. Downregulation of HSF $1 /$ hsp70 by TNF $\alpha$, however, is a transient effect. Previous investigations have shown that some cell types show an increased activation of HSF1 several hours after $\operatorname{TNF} \alpha$ stimulation. ${ }^{37,38}$ This effect was much slower and also weaker than the one induced by heat shock, nevertheless sufficient to increase hsp70 levels. ${ }^{37}$ In this case, TNF $\alpha$ can be considered as an extracellular stress factor, which induces HSF1/hsp70 as a part of a cellular defense and resistance strategy. However, this effect is slow and therefore an interaction with the rapid and decisive signaling events for inflammation or apoptosis is highly unlikely.

This transient downregulation of $\mathrm{HSF} 1 / \mathrm{hsp} 70$ by TNF $\alpha$ is a double-edged sword. Cells facing heat stress during this time interval are highly susceptible to apoptosis, since they lack the protective effects of hsp70 and thus are poorly prepared to cope with stress signals (Figure 9). Thus, hampered induction of hsp70 expression based on the blockade of serine hyperphosphorylation and thus activation of HSF1 seems to be the key event for a strongly increased susceptibility to apoptosis following TNF $\alpha$ exposure. This effect is mediated by TNF-R1, but not TNF-R2, and further downstream by the PPs PP1/PP2a and PP2b, rather than classical TNF-induced kinase signaling pathways, such as MAPK/SAPK, NF- $\kappa$ B and PKCs. Thus, PPs appear as key linker molecules between the cellular effects of $\mathrm{TNF} \alpha$, the activation of $\mathrm{HSF} 1 / \mathrm{hsp} 70$ stress responses and cellular susceptibility to apoptosis. Several points of evidence support this concept: (i) PPs PP1/PP2a and PP2b can be activated by $\mathrm{TNF} \alpha,{ }^{29,39}$ (ii) activation of these PPs increases susceptibility to apoptotic cell death, ${ }^{28,29}$ (iii) activation of PP1/PP2a and PP2b (calcineurin) as well as elevated intracellular calcium levels inhibit phosphorylation of HSF1 and thus activation of the HSF $1 /$ hsp70 stress response, ${ }^{40-42}$ (iv) hsp70, which acts in a negative-feedback loop on HSF1 activation, ${ }^{18}$ induces PP1/PP2a as well as $\mathrm{PP} 2 \mathrm{~b}$ and thus blocks continuing activation of $\mathrm{HSF}^{43,44}$ and (v) ERK and NF- $\kappa \mathrm{B}$ signaling, which maintained a certain responsiveness of $\mathrm{HSF} 1 / \mathrm{hsp} 70$ and also protected cells from apoptotic death, is a concurring mechanism to PPs, since their mutual inhibition has been repeatedly demonstrated. ${ }^{45,46}$

In summary, the data presented provide insights into the interplay of signals essential for cell survival, stress resistance and apoptosis. TNF $\alpha$ transiently suppresses the HSF $1 / \mathrm{hsp} 70$ stress response by engaging TNF-R1 and activating PPs
PP1/PP2a and PP2b. This may facilitate the later induction of proinflammatory responses of TNF $\alpha$, since hsp70 functions as an inhibitor of proinflammatory responses apart from its role in protecting cells from stress. However, the price for this is the loss of cell resistance mechanisms and thus an increased sensitivity to apoptotic death.

\section{Materials and Methods}

\section{Cell culture}

For cultivation of U937 macrophages, $1 \times 10^{6}$ cells were seeded into a $25 \mathrm{ml}$ flask (Falcon, Becton Dickinson \& Co., Oxnard, CA, USA) and cultivated in RPMI 1640 supplemented with $10 \%$ fetal calf serum (FCS), $1 \%$ L-glutamine and $1 \%$ penicillin-streptomycin in $5 \% \mathrm{CO}_{2}$ at $37^{\circ} \mathrm{C}$. Cell concentrations did not exceed $3 \times 10^{6}$ macrophages $/ \mathrm{ml}$ medium, and fresh medium was supplied every 3 days. The day before the experiments, viable cells were enriched by Ficoll-Paque (Pharmacia, Uppsala, Sweden) density gradient centrifugation.

\section{Treatment of cells}

Treatment of cells with TNF $\alpha$ was performed at a concentration of $10 \mathrm{ng} /$ $\mathrm{ml}$, except for dose-response curves $(0.5-50 \mathrm{ng} / \mathrm{ml})$. Heat stress was applied by heating the cells at $42^{\circ} \mathrm{C}$ for $30 \mathrm{~min}$. HSF1 activation was analyzed $30 \mathrm{~min}$ after start of heat stress; hsp70 expression was assessed $5 \mathrm{~h}$ after heat stress. For inhibition studies, the following reagents were used: anti-TNF-R1 monoclonal antibody (Mab) (clone H398, $10 \mu \mathrm{g} / \mathrm{ml}$, Serotec Ltd., Oxford, USA), anti-TNF-R2 Mab (clone M1, $10 \mu \mathrm{g} / \mathrm{ml}$, Serotec Ltd., Oxford, UK), caspase-1 inhibitor I (YVAD-CHO, $10 \mu \mathrm{M}$; Calbiochem, San Diego, CA, USA), caspase-3 inhibitor I (DEVD-CHO, $10 \mu \mathrm{M}$, Calbiochem), caspase-8 inhibitor I (IETD-CHO, $10 \mu \mathrm{M}$, Calbiochem), MEK-inhibitor (PD98059, $20 \mu \mathrm{M}$, Calbiochem), JNK1 inhibitor (LJNKI1, $20 \mu \mathrm{M}$; Alexis Biochemicals, San Diego, CA, USA), p38-kinase inhibitor (SB203580, $10 \mu \mathrm{M}$, Calbiochem), NF- $\kappa$ B-inhibitor (BAY 11-7085, $20 \mu \mathrm{M}$; Biomol Research Laboratories Inc., Plymouth Meeting, PA, USA), total PKC inhibitor (wortmannin, $20 \mathrm{nM}$, Alexis Biochemicals), PKC- $\zeta-$ inhibitor (myristoylated PKC- $\zeta-$ pseudosubstrate, $40 \mu \mathrm{M}$; Biosource, Camarillo, CA, USA), PP-1/2a inhibitor (okadaic acid, $0.5 \mu \mathrm{M}$, Calbiochem) and PP-2b inhibitor (FK506, $10 \mu \mathrm{M}$, Calbiochem). For inducing the production of TNF, $2 \times 10^{6}$ cells were stimulated with $0.5 \mu \mathrm{M} \mathrm{hsp70}$ or with $0.5 \mu \mathrm{M}$ hsp27 (used as control protein; both Stressgen Biotechnologies, Victoria, Canada) for 3 days. Cell culture supernatants were then measured for TNF content by ELISA (R\&D Diagnostics, Minneapolis, MN, USA), harvested and incubated with fresh U937 cells according to the above-mentioned protocols. Inhibition of TNF was performed by $1 \mu \mathrm{g} / \mathrm{ml}$ anti-human TNF antibody (Infliximab, Centocor; Leiden, The Netherlands).

\section{Protein extraction and Western blot analysis}

Cells $\left(5 \times 10^{6}\right)$ were washed twice in PBS, pelleted by centrifugation at $1200 \times g$ for $10 \mathrm{~min}$ and resuspended in $200 \mathrm{ml}$ of lysis buffer $(0.15 \mathrm{M}$ $\mathrm{NaCl}, 50 \mathrm{mM}$ Tris, $1 \mathrm{mM}$ EDTA, $0.05 \%$ SDS, 0.5\% Triton-X 100 and $1 \mathrm{mM}$ phenylmethylsulfonylfluoride, $\mathrm{pH} 7.4$ ) for $30 \mathrm{~min}$ at $4{ }^{\circ} \mathrm{C}$. The cell lysate was then centrifuged at $13000 \mathrm{rpm}$ for $10 \mathrm{~min}$, the supernatants were harvested and analyzed for their protein content using a protein assay kit (Bio-Rad, Hercules, CA, USA). For electrophoresis, total cell proteins were dissolved (1:2 vol/vol) in sample buffer (5\% $\beta$-mercaptoethanol, $15 \%$ glycerol, $3 \%$ SDS, $0.1 \mathrm{M}$ Tris; pH 6.8) and separated on a $12 \%$ SDS-gel under reducing conditions. Proteins were electrophoretically blotted onto 
nitrocellulose membranes (BA85, Schleicher \& Schuell, Dassel, Germany). Hsp70 expression was detected by probing the membranes with an Mab to human hsp70 (clone SPA 810, Stressgen Biotechnol. Corp., Victoria, BC, Canada) as described ${ }^{47}$ which specifically recognizes the inducible but not the constitutive members of the hsp70 family in human cells. HRP-conjugated rabbit anti-mouse Ig (Dako, Glostrup, Denmark) was used as detection antibody and the reaction visualized by 4-chloro-1-naphtol/hydrogen peroxide (Sigma, St. Louis, MO, USA). HSF1 expression was investigated using a rabbit polyclonal antibody against mammalian HSF1 (Stressgen Biotechnologies Corp.) and HRP-conjugated goat anti-rabbit Ig (Dako) for detection. Results were quantitated by Phospholmager (Bio-Rad). Immunoprecipitation of HSF1 from cell extracts was carried out by addition of $5 \mu \mathrm{g} / \mathrm{ml}$ anti-HSF1 antibody and $10 \%$ (vol/vol) protein A-Sepharose beads. Precipitated HSF1 was then probed with biotinylated antiphosphoserine $\mathrm{Ab}$ (Sigma) and the reaction was visualized by HRP-streptavidin.

\section{EMSA}

For analysis of HSF1 transcription factor activity, nuclear protein extracts from U937 cells were used. Isolation of nuclear protein was similar to that described by Schreiber ${ }^{48}$ with slight modification. ${ }^{37}$ After washing, $2 \times 10^{6}$ U937 cells in cold TBS ( $10 \mathrm{mM}$ Tris, $150 \mathrm{mM} \mathrm{NaCl}, 1 \mathrm{mM}$ EDTA, pH 7.4), the cells were pelleted and $400 \mu$ of cold buffer A (10 mM HEPES, $10 \mathrm{mM}$ $\mathrm{KCl}, 0.1 \mathrm{mM}$ EGTA, $1 \mathrm{mM}$ DTT, $1 \mathrm{mM}$ Pefablock SC, $0.5 \mathrm{mM}$ PMSF, $1 \mu \mathrm{g} /$ $\mathrm{ml}$ aprotinin, $1 \mu \mathrm{g} / \mathrm{ml}$ leupeptin, $\mathrm{pH}$ 7.9) was added. The suspension was incubated on ice for $15 \mathrm{~min}$ after pipetting in a yellow tip. Then, $25 \mu \mathrm{l}$ Nonidet P-40 (10\% vol/vol) was added, the suspension vortexed for $10 \mathrm{~s}$ and centrifuged for $30 \mathrm{~s}$ at $13000 \mathrm{rpm}$. The supernatant was discarded and the nuclear pellet incubated with $50 \mu \mathrm{l}$ of cold buffer B $(20 \mathrm{mM}$ HEPES, $0.4 \mathrm{M} \mathrm{NaCl}, 1 \mathrm{mM}$ EGTA, $1 \mathrm{mM}$ EDTA, $1 \mathrm{mM}$ DTT, $1 \mathrm{mM}$ Pefablock SC, $0.5 \mathrm{mM}$ PMSF, $1 \mu \mathrm{g} / \mathrm{ml}$ aprotinin, $1 \mu \mathrm{g} / \mathrm{ml}$ leupeptin, $\mathrm{pH}$ 7.9 ) at $4{ }^{\circ} \mathrm{C}$ for $15 \mathrm{~min}$ on a gyratory shaker platform with vigorous rocking. The suspension was then centrifuged at $4^{\circ} \mathrm{C}$ for $5 \mathrm{~min}$ at $13000 \mathrm{rpm}$, the supernatant collected and protein concentration determined.

EMSA was performed as described previously. ${ }^{37}$ Briefly, DNA binding was determined following incubation of $5 \mathrm{mg}$ of nuclear protein with $10 \mathrm{fmol}$ of an oligonucleotide containing the heat shock element (HSE) sequence from the Drosophila hsp70 promotor $\left(5^{\prime}\right.$ GCCTCGAATGTTCGCGAAGTTT-3') labeled with ${ }^{32} \mathrm{P}$-dCTP. Reaction buffer contained $10 \mathrm{mM}$ HEPES, pH 7.9, $1 \mathrm{mM}$ DTT, $1 \mathrm{mM}$ EDTA, $80 \mathrm{mM}$ $\mathrm{KCl}, 4 \%$ Ficoll and $1 \mu \mathrm{g}$ poly (dldC) (Pharmacia Biotech, Uppsala, Sweden) as a nonspecific competitor. Samples were electrophoresed on $4 \%$ polyacrylamide gels in $0.5 \times$ TBE $(1 \times$ TBE: $89 \mathrm{mM}$ Tris, $89 \mathrm{mM}$ boric acid, $20 \mathrm{mM}$ EDTA, pH 8.3). Then, the gel was dried and exposed to autoradiographic film. For supershift analysis, polyclonal Abs to HSF1 and HSF2 (Stressgen Biotechnologies Corp.) were used.

\section{FACS analysis}

Detection of early-stage apoptosis by annexin $\mathrm{V}$ staining

Cells were analyzed for their capacity to bind recombinant human annexin V, directly conjugated to FITC (Roche Diagnostics, Boehringer Ingelheim Bioproducts Partnership). Cells were pelleted, washed in annexin Vbinding-buffer (ABB) containing $1.8 \mathrm{mM} \mathrm{CaCl} 2$ according to the manufacturer's guidelines, resuspended in $200 \mu \mathrm{l} A B B$ with $5 \mu$ lannexin V-FITC and incubated for $15 \mathrm{~min}$ at room temperature. Following washing in $\mathrm{ABB}, \mathrm{PI}$ was added to a final concentration of $1 \mu \mathrm{g} / \mathrm{ml}$ and samples were analyzed on an FACScan (Becton Dickinson Immunocytometry Systems, San Jose, CA, USA) by dual color cytofluorometry. Cells that stained brightly with annexin $\mathrm{V}$ but still excluded PI were considered to be earlyphase apoptotic. $^{49}$

\section{Simultaneous analyses of hsp70 expression and DNA} fragmentation

TUNEL was performed using an In Situ Cell Death Detection Kit (Boehringer Mannheim, Mannheim, Germany) according to the manufacturer's recommendations. ${ }^{50}$ Negative controls treated exactly the same way except addition of terminal deoxynucleotidyl transferase (TdT) were included for determination of the autofluorescence baseline. Following final TUNEL washes, pelleted cells were resuspended in $50 \mu \mathrm{l}$ of a $1: 10$ dilution $(10 \mu \mathrm{g} / \mathrm{ml}$ final) of unconjugated mouse anti-human HSP-70 antibody in PBS and incubated for $1 \mathrm{~h}$ at $4^{\circ} \mathrm{C}$. In parallel, negative control samples were incubated with an equivalent amount of isotype-matched, unconjugated mouse IgG2a negative control antibody (Dako). Subsequently, all samples were washed once in PBS and resuspended in $50 \mu \mathrm{l}$ of $1: 10$ diluted $F\left(a b^{\prime}\right) 2$ fragments of rabbit anti-mouse lg antibody conjugated to R-phycoerythrin (Dako) in PBS and incubated for $30 \mathrm{~min}$ at $4^{\circ} \mathrm{C}$. Following a final wash, samples were analyzed by dual color immunocytofluorometry.

\section{Statistical analysis}

Unpaired Student's $t$-test was used to assess the differences between two groups. A $P$-value of less than 0.05 was considered as significant.

\section{Acknowledgements}

This study was supported by the Center of Molecular Medicine of the Austrian Academy of Sciences (G Steiner), a grant from the Austrian National Bank (project $8715, \mathrm{G}$ Schett) and the START price of the Austrian Federal Ministry of Sciences (G Schett).

\section{References}

1. Tracey KJ and Cerami A (1993) Tumor necrosis factor, other cytokines and disease. Ann. Rev. Cell. Biol. 9: 317-343.

2. Baud V and Karin M (2001) Signal transduction by tumor necrosis factor and its relatives. Trends Cell. Biol. 11: 372-377.

3. Vandenabeele P, Declercq W, Beyaert R and Fiers W (1995) Two tumor necrosis factor receptors: structure and function. Trends Cell. Biol. 5: 392-399.

4. Barnes PJ and Karin M (1997) Nuclear factor-B: a pivotal transcription factor in chronic inflammatory diseases. New Engl. J. Med. 336: 1066-1071.

5. Karin M, Liu Z and Zandi E (1997) AP-1 function and regulation. Curr. Opin. Cell. Biol. 9: 240-246.

6. Chang HY and Yang $X$ (2000) Proteases for cell suicide: functions and regulation of caspases. Microbiol. Mol. Biol. Rev. 64: 821-846.

7. Morimoto RI (1993) Cells in stress: transcriptional activation of heat shock genes. Science 259: 1409-1410.

8. Lindquist S and Craig EA (1988) The heat shock proteins. Ann. Rev. Genet. 22: 631-677.

9. Morimoto RI, Tissieres A and Georgopoulous C (1990) The stress response, function of the proteins, and perspectives. In Stress proteins in Biology and Medicine, Morimoto RI, Tissieres A, Georgopoulous C (eds) (Cold Spring Harbor, NY: Cold Spring Harbour Laboratory Press), pp. 1-37.

10. Schlesinger MJ (1990) Heat shock proteins. J. Biol. Chem. 265: 12111-12114. 
11. Jaattela M, Wissing D, Bauer PA and Li GC (1992) Major heat shock protein 70 , hsp70, protects tumor cells from tumor necrosis factor cytotoxicity. EMBO J. 11: 3507-3512.

12. Samali A and Cotter TG (1996) Heat shock proteins increase resistance to apoptosis. Exp. Cell. Res. 223: 163-170.

13. Gabai VL, Zamulaeva IV, Mosin AF, Makarova YM, Mosina VA, Budagova KR Malutina YV and Kabakoy AE (1995) Resistance of Ehrlich tumor cells to apoptosis can be due to accumulation of heat shock proteins. FEBS Lett. 375 : 21-26.

14. Park HS, Lee JS, Huh SH, Seo JS and Choi EJ (2001) Hsp72 functions as a natural inhibitory protein of C-jun-N-terminal kinase. EMBO J. 20: 446-456.

15. Wang JH, Yao MZ, Gu JF, Sun LY, Shen YF and Liu XY (2002) Blocking HSF1 by dominant-negative mutant to sensitize tumor cells to hyperthermia. Biochem. Biophys. Res. Commun. 290: 1454-1461.

16. Jaattela M, Wissing D, Kokholm K, Kallunki T and Egeblad M (1998) Hsp70 exerts its antiapoptotic function downstream of caspase-3-like proteases. EMBO J. 17: 6124-6134.

17. Schett G, Steiner CW, Gröger M, Winkler S, Graninger W, Smolen JS, Xu Q and Steiner G (1999) Activation of Fas inhibits heat-induced activation of HSF1 and upregulation of hsp70. FASEB J. 13: 833-842.

18. Kim D, Ouyang $H$ and Li GC (1995) Heat shock protein hsp70 accelerates the recovery of heat-shocked mammalian cells through its modulation of heat shock transcription factor HSF1. Proc. Natl. Acad. Sci. USA 92: 2126-2130.

19. Wang Y, Kelly CG, Sigh M, McGowan EG, Carrara AS, Bergmeier LA and Lehner $T$ (2002) Stimulation of Th1-polarizing cytokines, C-C chemokines, maturation of dendritic cells, and adjuvant function of the peptide binding fragment of heat shock protein 70. J. Immunol. 269: 2422-2429.

20. Natoli G, Costanzo A, lanni A, Templeton DJ, Woodgett JR, Balsano $C$ and Levrero M (1997) Activation of SAPK/JNK by TNF receptor 1 through a noncytotoxic TRAF2-dependent pathway. Science 275: 200-203.

21. Varghese J, Chattopadhaya S and Sarin A (2001) Inhibition of p38 kinase reveals a TNF-alpha-mediated, caspase-dependent, apoptotic death pathway in a human myelomonocyte cell line. J. Immunol. 166: 6570-6577.

22. Sanz L, Sanchez P, Lallena MJ, Diaz-Meco MT and Moscat J (1999) The interaction of $p 62$ with RIP links the atypical PKCs to NF-B activation. EMBO J. 18: 3044-3053.

23. Ichijo $H$, Nishida $E$, Irie $K$, ten Dijke $P$, Saitoh $M$, Moriguchi T, Takagi M, Matsumoto K, Miyazono K and Gotoh Y (1997) Induction of apoptosis by ASK1, a mammalian MAPKKK that activates SAPK/JNK and p38 signaling pathways. Science 275: 90-94

24. Xia Z, Dickens M, Raingeaud J, Davis RJ and Greenberg ME (1995) Opposing effects of ERK and JNK-p38 MAP kinases on apoptosis. Science 270: 1326-1331.

25. Hsu H, Shu HB, Pan MG and Goeddel DV (1996) TRADD-TRAF2 and TRADD-FADD interactions define two distinct TNF receptor 1 signal transduction pathways. Cell 84: 299-308.

26. Rath PC and Aggarwal BB (1999) TNF-induced signaling in apoptosis. J. Clin. Immunol. 19: 350-364.

27. Yeh WC, Pompa JL, McCurrach ME, Shu, HB, Elia AJ, Shahinian A, Ng M, Wakeham A, Khoo W, Mitchell K, El-Deiry WS, Lowe SW, Goeddel DV and Mak TW (1998) FADD: essential for embryo development and signaling from some, but not all, inducers of apoptosis. Science 279: 1954-1958.

28. Santoro MF, Annand RR, Robertson MM, Peng YW, Brady MJ, Mankovich JA, Hackett MC, Ghayur T, Walter G, Wong WW and Giegel DA (1998) Regulation of protein phosphatase $2 \mathrm{~A}$ activity by caspase-3 during apoptosis. J. Biol. Chem. 273: 13119-13128.

29. Kantrow SP, Gierman JL, Jaligam VR, Zhang P, Piantadosi CA, Summer WR and Lancaster JR (2000) Regulation of tumor necrosis factor cytotoxicity by calcineurin. FEBS Lett. 483: 119-124.

30. Deveraux QL and Reed JC (1999) IAP family proteins - suppressors of apoptosis. Genes Dev. 13: 239-252.

31. Malhotra V and Wong HR (2002) Interactions between the heat shock response and the nuclear factor-kappa B signaling pathway. Crit. Care Med. 30 (Suppl): S89-S95.
32. Thomas SC, Ryan MA, Shanley TP and Wong HR (1998) Induction of the stress response with prostaglandin $A 1$ increases I-kappaB alpha gene expression. FASEB J. 12: 1371-1378.

33. Yoo CG, Lee S, Lee CT, Kim YW, Han SK and Shim YS (2000) Antiinflammatory effect of heat shock protein induction is related to stabilization of I kappa B alpha through preventing I kappa B kinase activation in respiratory epithelial cells. J. Immunol. 164: 5416-5423.

34. Singh IS, He JR, Calderwood S and Hasday JD (2002) A high affinity HSF1 binding site in the $5^{\prime}$-untranslated region of the murine tumor necrosis factoralpha gene is a transcriptional repressor. J. Biol. Chem. 277: 4981-4988.

35. Kluger MJ, Rudolph K, Soszynski D, Conn CA, Leon LR, Kozak W, Wallen ES and Moseley PL (1997) Effect of heat stress on LPS-induced fever and tumor necrosis factor. Am. J. Physiol. 273: R858-R863.

36. Xiao X, Zuo X, Davis AA, McMillan DR, Curry BB, Richardson JA and Benjamin IJ (1999) HSF1 is required for extra-embryonic development, postnatal growth and protection during inflammatory responses in mice. EMBO J. 18: 59435952.

37. Schett G, Redlich K, Xu Q, Bitzan P, Gröger M, Tohidast-Akrad M, Kiener H, Smolen J and Steiner $G$ (1998) Enhanced expression of heat shock protein 70 (hsp70) and heat shock factor 1 (HSF1) activation in rheumatoid arthritis synovial tissue. J. Clin. Invest. 102: 302-311.

38. Heimbach JK, Reznikov LL, Calkins KM, Robinson TN, Dinarello CA, Harken $\mathrm{AH}$ and Meng $\mathrm{X}$ (2001) TNF receptor I is required for induction of macrophage heat shock protein 70. Am. J. Physiol. 281: C241.

39. Medcalf RL (1992) Cell- and gene-specific interactions between signal transduction pathways revealed by okadaic acid. Studies on the plasminogen activating system. J. Biol. Chem. 267: 12220-122260.

40. Mivechi NF, Murai T and Hahn GM (1994) Inhibitors of tyrosine and Ser/Thr phosphatases modulate the heat shock response. J. Cell. Biochem. 54: 186197.

41. Soncin F, Asea A, Zhang X, Stevenson MA and Calderwood SK (2000) Role of calcium activated kinases and phosphatases in heat shock factor-1 activation. Int. J. Mol. Med. 6: 705-710.

42. Kiang JG, Gist ID and Tsokos GC (2000) Regulation of heat shock protein $72 \mathrm{kDa}$ and $90 \mathrm{kDa}$ in human breast cancer MDA-MB-231 cells. Mol. Cell. Biochem. 204: 169-178.

43. Ding XZ, Tsokos GC and Kian JG (1998) Overexpression of HSP-70 inhibits the phosphorylation of HSF1 by activating protein phosphatase and inhibiting protein kinase $C$ activity. FASEB J. 12: 451-459.

44. Someren JS, Fabe LE, Klein JD and Tumlin JA (1999) Heat shock proteins 70 and 90 increase calcineurin activity in vitro through calmodulin-dependent and independent mechanisms. Biochem. Biophys. Res. Commun. 260: 619-625.

45. Zhou B, Wang ZX, Zhao Y, Brautigan DL and Zhang ZY. (2002) The specificity of extracellular signal-regulated kinase 2 dephosphorylation by protein phosphatases. J. Biol. Chem. 277: 31818-31835.

46. Nasuhara Y, Adcock IM, Catley M, Barnes PJ and Newton R (1999) Differential IkappaB kinase activation and IkappaBalpha degradation by interleukin-1beta and tumor necrosis factor-alpha in human U937 monocytic cells. Evidence for additional regulatory steps in kappaB-dependent transcription. J. Biol. Chem. 274: 19965-19972.

47. Xu Q, Ganju L, Fawcett TW and Holbrook NJ (1996) Vasopressin-induced heat shock protein expression in renal tubular cells. Lab. Invest. 74: 178-187.

48. Schreiber E, Mathias P, Müller MM and Schaffner WR (1989) Rapid detection of octamer binding proteins with 'mini-extracts', prepared from a small number of cells. Nucleic Acid Res. 17: 6419.

49. Vermes I, Haanen C, Steffens-Nauken $H$ and Reutelingsberger C (1995) A novel assay for apoptosis: flow cytometric detection of phosphatidylserine expression on early apoptotic cells using fluorescein labelled Annexin V. J. Immunol. Methods 184: 39-51.

50. Sgonc R, Boeck G, Dietrich H, Gruber J, Recheis H and Wick G (1994) Simultaneous detection of cell surface antigens and apoptosis. Trends Genet. 10: $41-42$. 